\title{
SYNTHESIS, CHARACTERIZATION, AND APPLICATION OF THE MESOPOROUS MOLECULAR SIEVE SR-MCM-41 IN THE REMOVAL OF NAPHTHENIC ACIDS FROM A MODEL MIXTURE OF AVIATION KEROSENE BY ADSORPTION
}

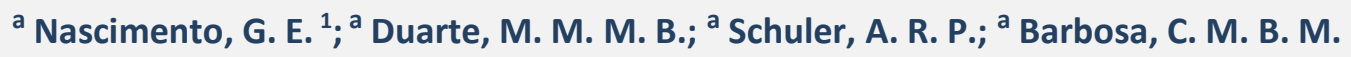 \\ ${ }^{a}$ Chemical Engineering Department, Federal University of Pernambuco, Recife, PE, Brazil
}

\begin{abstract}
The MCM-41 mesoporous molecular sieves have attracted a great deal of interest due to their application in adsorption processes, like in the removal of naphthenic acids, which are directly responsible for acidity and corrosiveness of petroleum. The objective of this work is to explore the synthesis, characterization, and application of Sr-MCM-41 in removing naphthenic acids from a model mixture of aviation kerosene (jet fuel) by adsorption. The adsorbent was characterized and a factorial design was used to determine the best operating conditions. The characterization results indicated that the incorporation of strontium did not compromise the mesoporous structure, and that the material showed a good degree of organization. The factorial design indicated that the highest adsorption capacity was obtained for an acid concentration of $7 \mathrm{wt} . \%$, an adsorbent amount of $0.01 \mathrm{~g}$, and a stirring speed of $420 \mathrm{rpm}$. This study demonstrates the potential of this adsorbent for the removal of the naphthenic acids that are present in jet fuel.
\end{abstract}

\section{KEYWORDS}

naphthenic acids; MCM-41; jet fuel; adsorption; factorial design

\footnotetext{
${ }^{1}$ To whom all correspondence should be addressed.

Address: Chemical Engineering Department, Federal University of Pernambuco, Avenida Artur de Sá, s/n, Recife-PE, Brazil. CEP: 50740-521 | Telephone/Fax number: +55812126-7291/ +55 21 2126-7278 |e-mail: grazielen@yahoo.com.br doi:10.5419/bjpg2014-0001
} 


\section{INTRODUCTION}

A new family of ordered mesoporous molecular sieves designated as M41S was first discovered by Mobil Company in 1992 (Beck et al., 1992). Since then, a great deal of interest has arisen in studying its properties and applications due to their large specific surface area and narrow and controllable pore-size distributions. These factors make M41S a promising candidate for use as adsorbents, catalysts, and supports(Jiang et al., 2007; Northcott et al., 2010; Zhao et al., 2011).

The basic mesoporous molecular sieve is formed of amorphous silica, and it contains a considerable amount of silanol groups. To expand the field of applications, there is still a need to improve the synthesis of molecular sieves by replacing silicon (Si) with other ions. The incorporation of heteroatoms in the walls of MCM-41 allows one to control its features and, thus, obtain materials with predetermined properties (Oliveira et al., 2005). Molecular sieves with more basic or acidic sites can be generated as required by the desired application (Silva, 2009c; Li et al., 2010).

The incorporation of transition (Nilsen et al., 2007; Anunziata et al., 2008), rare earth (Zhan et al., 2008), and alkaline earth metals (Silva, 2007a; Wu et al., 2011) into MCM-41 produces new types of adsorbents that can be used in various applications, such as removing contaminants from petroleum.

Among the different types of petroleum products, aviation kerosene is the fuel used in aircraft turbine engines. It is produced by the fractionation of petroleum by distillation at atmospheric pressure.

Jet fuel is composed of paraffinic, naphthenic, aromatic, and olefinic hydrocarbons, in addition to polluting sulfur-, nitrogen-, and oxygen-containing compounds, and must undergo to specific treatments to eliminate the problems caused by these compounds, especially by the naphthenic acids (Silva, 2009b).

Naphthenic acids are classified as carboxylic mono-acids with general formula $\mathrm{R}\left(\mathrm{CH}_{2}\right) \mathrm{nCOOH}$, where $\mathrm{R}$ is some cycloaliphatic structure (Petkova et al., 2009). The presence of these acids in various amounts in crude oil and its derivatives is one of the most challenging problems for the oil industry.
These contaminants can lead to problems such as corrosion (Hau, 2009), equipment failure, high maintenance costs, reduced product quality, and can cause disposal problems due to environmental concerns (Petkova et al., 2009).

The methods that are currently in use to remove these acids include caustic washing, hydrorefining, and refining with ammonia and solvents. However, there are many disadvantages to these methods, such as high operating costs and performance problems (Huang et al., 2006).

In an attempt to solve these problems, various techniques have been researched for removing these compounds effectively and non-destructively. According to Ding et al. (2009), naphthenic acids can be removed by non-destructive processes such as adsorption, and can be purified and further commercialized for other purposes.

Various adsorbents, such as ion exchange resins (Gaikar\&Maiti, 1996; Silva, 2007b), commercial clays (Zou et al., 1997; Silva, 2007b; Silva et al., 2013 ); zeolites, silica gel, calcite, and mica (RezaeiGomari et al., 2006); activated alumina (Silva, 2007b); cyclodextrin polymer (Mohamed et al., 2008); activated carbon (Mohamed et al., 2008); and modified perovskites (Silva, 2009b) have undergone laboratory tests for the removal of naphthenic acids from petroleum. These adsorbents, however, showed limited success.

Given these considerations, this work synthesized and characterized a mesoporous molecular sieve featuring the incorporation of the alkaline earth metal strontium (Sr-MCM-41) to confer basic features. The material was evaluated for the removal of the naphthenic acids that were present in a model mixture of jet fuel (n-dodecanoic acid in $\mathrm{n}$-dodecane solution) in a finite batch system using a $2^{3}$ factorial design to determine the best working conditions.

\section{MATERIALS AND METHODS}

\subsection{Synthesis of mesoporous molecular sieve Sr-MCM-41}

The molecular sieve Sr-MCM-41 was synthesized using the hydrothermal method according to Silva (2007a), who used an adaptation of the method 
developed by Cai et al. (1999). The silica gel (95\% purity, Merck) and the sodium silicate $\left(\mathrm{Na}_{2} \mathrm{O}-28 \%\right.$ purity, Vetec; $\mathrm{SiO}_{2}-28 \%$ purity, Vetec) were used as silicon sources. The cetyltrimethylammonium bromide (CTMABr) (99\% purity, Merck) served as a structural template, and the strontium acetate $(98 \%$ purity, Vetec) provided the strontium source. The synthesis was conducted at $100^{\circ} \mathrm{C}$ in a jacketed stainless steel Teflon $^{\circledR}$ autoclave in a volume of 45 $\mathrm{mL}$ for a period of 5 days. The molar composition of the resulting gel was $1 \mathrm{CTMABr}: 4 \mathrm{SiO}_{2}: \mathrm{Na}_{2} \mathrm{O}$ 1: 0.2 SrO: $200 \mathrm{H}_{2} \mathrm{O}$.

The synthesis procedure entailed the preparation of two solutions. In solution 1, silica was added to sodium silicate, strontium acetate, and half of the volume of distilled water required for synthesis. The system was subjected to stirring for 2 hours at $60^{\circ} \mathrm{C}$. While solution 1 was stirring, solution 2 was prepared using the CTMABr and the other half of the distilled water. Solution 2 was placed under stirring at room temperature $\left(25 \pm 2^{\circ} \mathrm{C}\right)$ for 30 minutes until complete dissolution. Then, the solution 1 was added to the solution 2 , and the mixture was further stirred for 1 hour at room temperature.

The obtained gel was transferred to a Teflon $^{\circledR}$ vessel, sealed in a stainless steel autoclave, and placed in an oven preheated to $100 \pm 1^{\circ} \mathrm{C}$ during 5 days with daily adjustments to the $\mathrm{pH}$ in the range of 9.5 to 10 using a solution of $30 \%$ acetic acid.

After this period, the autoclave was removed from the oven and cooled to room temperature. The crystallized material was washed first with distilled water and, then, with a solution of $2 \%$ hydrochloric acid in ethanol to remove part of the surfactant. Finally, the resulting solid was subjected to drying in an oven at $100^{\circ} \mathrm{C}$ for 6 hours.

The calcination of the adsorbent occurred in two stages where, initially, the sample was subjected to a heating ramp of $5^{\circ} \mathrm{C} \mathrm{min}{ }^{-1}$, starting from ambient temperature to $500^{\circ} \mathrm{C}$ in an inert atmosphere of argon at a flow rate of $100 \mathrm{~mL} \mathrm{~min}{ }^{-1}$. After the temperature reached $500^{\circ} \mathrm{C}$, the system remained in this condition for 1 hour. The argon flow was then replaced with oxygen at a flow rate of $100 \mathrm{~mL} \mathrm{~min}^{-1}$ for an additional hour. This calcination process aimed to remove the structural template present in the pores of the adsorbent. After this procedure, the adsorbent Sr-MCM-41 was classified using a 100 mesh Tyler sieve BERTEL. The fraction that passed through the 100 mesh sieve was used in subsequent experiments.

\subsection{Characterization of mesoporous molecular sieve Sr-MCM-41}

\subsubsection{Thermal analysis (TG/DTG)}

The thermogravimetric curves were obtained in a thermobalance (SHIMADZU, model TGA-50), under an atmosphere of nitrogen with a flow rate of $100 \mathrm{~mL} \mathrm{~min}^{-1}$. In this analysis, $5.0 \pm 0.5 \mathrm{mg}$ of sample was placed in an alumina crucible. It was used a heating rate of $10^{\circ} \mathrm{C} \mathrm{min}^{-1}$ in the range of 25 to $900^{\circ} \mathrm{C}$.

\subsubsection{X-ray diffraction (XRD)}

The samples were characterized on an X-ray diffractometer (SHIMADZU, model XRD-6000 $\theta-2 \theta$ ) using a CuK $\alpha$ radiation source with $30 \mathrm{kV}$ and $30 \mathrm{~mA}$. The data were collected in the $2 \theta$ range from $2^{\circ}$ to $10^{\circ}$, with steps of $0.01^{\circ}$ and a step time of 2 seconds.

\subsubsection{Textural characterization $\left(\mathbf{N}_{2}\right.$ adsorption/desorption by BET and BJH methods)}

The textural characterization was performed by the adsorption/desorption of nitrogen using the BET and BJH methods to determine the specific surface area, volume, and average diameter pore of the adsorbent. For this, it was used the BELSORP-MINI apparatus (Bel Japan Inc.). Initially, $50 \pm 0.5 \mathrm{mg}$ of the sample, calcined as indicated previously, was pretreated under vacuum to $333 \mathrm{~K}$ during 3 hours to remove moisture from the surface of the solid.

\subsubsection{Chemical analysis}

A sample of $1 \mathrm{~g}$ of the adsorbent was subjected to an acid digestion process, which consisted of the addition of hydrofluoric acid (HF-p.a., Vetec), hydrochloric acid $(\mathrm{HCl}-$ p.a., Vetec), and nitric acid ( $\mathrm{HNO}_{3}$-p.a.,Vetec). Then, the sample was analyzed by inductively coupled plasma optical emission spectroscopy (ICP-OES) using the SPECTRO apparatus (model SpectroCiros), which quantified the strontium concentration. The equipment operated at $1.4 \mathrm{~kW}$, with an argon flow rate of $12 \mathrm{~L}$ $\mathrm{min}^{-1}$, using an ultrasonic nebulizer with a concentric glass tube and a sample flow rate of $1.1 \mathrm{~mL} \mathrm{~min}^{-1}$. 


\subsubsection{Fourier transform infrared spectroscopy (FT-IR)}

The absorption spectra in the infrared region were obtained in an infrared absorption spectrophotometer (SHIMADZU, IR Prestige-21) using $\mathrm{KBr}$ as a dispersing agent. The tablets were prepared by mixing the sample with a sufficient mass $\mathrm{KBr}$ to achieve a concentration of $2 \mathrm{wt} . \%$. Following, the mixture was homogenized in a mortar, transferred to the pellet press die, and subjected to a pressure of 5 ton $\mathrm{cm}^{-2}$; forming a thin translucent pellet. The spectra were obtained in the $4000-400 \mathrm{~cm}^{-1}$ region, using $4 \mathrm{~cm}^{-1}$ resolution and 20 scans.

\subsubsection{Scanning electron microscopy with energy dispersive spectroscopy (SEM/EDS)}

The energy dispersive X-ray spectrum and scanning electron microscopy images of the sample were obtained using an energy dispersive spectrophotometer linked to the SHIMADZU Superscan SS-550 scanning electron microscope at $15 \mathrm{kV}$. The material for analysis was prepared by depositing a portion of the tape sample on carbon, followed by the deposition of a thin gold layer to improve the conduction of the sample.

\subsection{Model mixture of aviation kerosene (jet fuel)}

$\mathrm{N}$-dodecanoic carboxylic acid $\left(\mathrm{C}_{12} \mathrm{H}_{24} \mathrm{O}_{2}\right)$ was selected as the model compound to represent naphthenic acids in petroleum based on studies by Silva (2007a) and Silva (2009b). This acid was used in adsorption tests due to its physical properties and similarity with acidic compounds that are frequently encountered in aviation fuel. Solutions of this acid were prepared by employing $\mathrm{n}$-dodecane as solvent. The $\mathrm{n}$-dodecane is a hydrocarbon that belongs to the family of alkanes and has the chemical formula
$\mathrm{C}_{12} \mathrm{H}_{26}$, which is representative of jet fuel.

\subsection{Analysis of the concentration of naphthenic acids}

The concentration of naphthenic acid ( $n$ dodecanoic acid) was analyzed using a gas chromatograph (Ciolo \& Gregory; GC MASTER), with a column Fl-547 $(25 \mathrm{~m} \times 0.25 \mathrm{~mm} \times 1 \mu \mathrm{m})$ and an ionization detector (FID). The following conditions were used: isothermal oven temperature of $200^{\circ} \mathrm{C}$; vaporizer temperature of $220^{\circ} \mathrm{C}$; detector temperature of $240^{\circ} \mathrm{C}$; hydrogen mobile phase at a flow rate of $1.7 \mathrm{~mL} \mathrm{~min}^{-1}$ and pressure of $3 \mathrm{psi}$; and an injected volume of $1 \mu \mathrm{L}$. The Peak Simple II (SRI Instruments, USA) software was used for data acquisition.

\subsection{Assessment of working conditions}

To achieve greater efficiency in the adsorptive process, the experiments were conducted using a $2^{3}$ factorial design to observe the influence of the variables on the process and to determine the best working conditions. The assays were performed in random order, and the center point was determined in triplicate to ensure the reproducibility of the experimental data. In this work, it was evaluated the following variables: adsorbent mass (g), acid concentration (wt.\%), and stirring speed (rpm).

The efficiency of the adsorption process was quantified by the amount of solute adsorbed per unit mass of the adsorbent or the adsorptive capacity $q$ (gacid $\mathrm{g}^{-1}$ adsorbent) obtained by Equation 1.

$$
q_{e}=\frac{\left(C_{o}-C_{f}\right) V}{M_{a d s}}
$$

Where $C_{o}=$ initial acid concentration in solution $(\mathrm{mg} / \mathrm{L}), C_{f}=$ concentration of acid in solution at equilibrium ( $\left.\mathrm{mg} \mathrm{L}^{-1}\right), V=$ volume of solution (L) and $M_{a d s}=$ adsorbent mass used (g). Table 1 shows the levels of the factors for the $2^{3}$ factorial design.

Table 1. Factor levels for the $2^{3}$ factorial design with central point for tests with adsorbent Sr-MCM-41.

\begin{tabular}{cccc}
\hline Variables & \multicolumn{2}{c}{ Levels } & +1 \\
\hline Adsorbent mass (g) & -1 & 0 & 0.15 \\
Acid concentration (wt.\%) & 0.05 & 0.10 & 7 \\
Stirring speed (rpm) & 3 & 5 & 420 \\
\hline
\end{tabular}




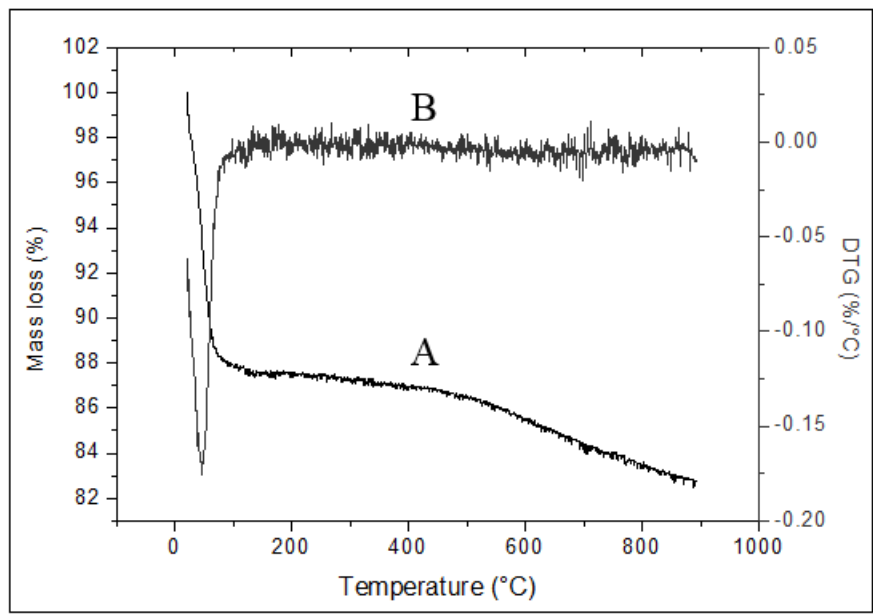

Figure 1. TG (A) and DTG (B) curves to the adsorbent Sr-MCM-41.

The tests were performed in a finite batch system using a $50 \mathrm{~mL}$ Erlenmeyer flask containing $5 \mathrm{~mL}$ of the solution of naphthenic acid in the concentrations shown in Table 1, for a period of 480 minutes. The tests were conducted at laboratory ambient temperature $\left(25^{\circ} \mathrm{C} \pm 2^{\circ} \mathrm{C}\right)$ with the aid of a shaker (IKA, KS 130C). The analysis of the concentration of naphthenic acids was performed before the start of experiments and at the end of each test, after filtration of samples. Blank tests were performed by following the same procedure.

The effects of the factors and the interactions among them, with their respective standard errors, were calculated according to Barros Neto et al. (2007), using the Statistica 6.0 software.

\section{RESULTS AND DISCUSSION}

\subsection{Characterization of mesoporous molecular sieve Sr-MCM-41}

\subsubsection{Thermal analysis (TG/DTG)}

The thermogravimetric analysis (TG) and differential thermogravimetry (DTG) curves are shown in Figure 1.

The TG curve (Figure 1A) confirms that three mass-loss events occur for the adsorbent Sr-MCM41 , with two being very well defined and one being less obvious. The first mass loss of $11.17 \%$ is attributed to the desorption of physically-adsorbed water. The second mass loss is on the order of
$2.39 \%$, and it is ascribed to the decomposition of the surfactant occluding the pores of the adsorbent. After the decomposition of the surfactant, the third mass loss of $3.76 \%$ occurs, which results from the condensation on the silanol groups' inner pore surfaces interacting with the template's molecules. The DTG curve shows the temperatures at which the mass losses occur. These results are in agreement with those found by Araujo and Jaroniec (2000), Silva (2007a), Park et al. (2007), Zhang et al. (2011), and Ghorbani et al. (2013), who also found three mass losses.

\subsubsection{X-ray diffraction (XRD)}

Diffractograms of the prepared materials were obtained before and after calcination and are shown in Figure 2.

The synthesized material shows an X-ray pattern similar to the one presented in the literature (Beck et al., 1992; Chien et al., 2005; Silva, 2007a; Saladino et al., 2011; Fu et al., 2011; Du \& Yang, 2012; Ghorbani et al., 2013) for mesoporous materials. The pattern shows the presence of plane (100), which is compatible with the standard MCM41; and of planes (110), (200), and (210), which are characteristic of a well-organized mesoporous material. The presence of these characteristic peaks indicates that the incorporation of strontium did not compromise the structural order. After calcination, there was an increase in peak intensities, suggesting a greater degree of organization in the sample and showing that the removal of the template did not affect the Sr-MCM-41 structure. 


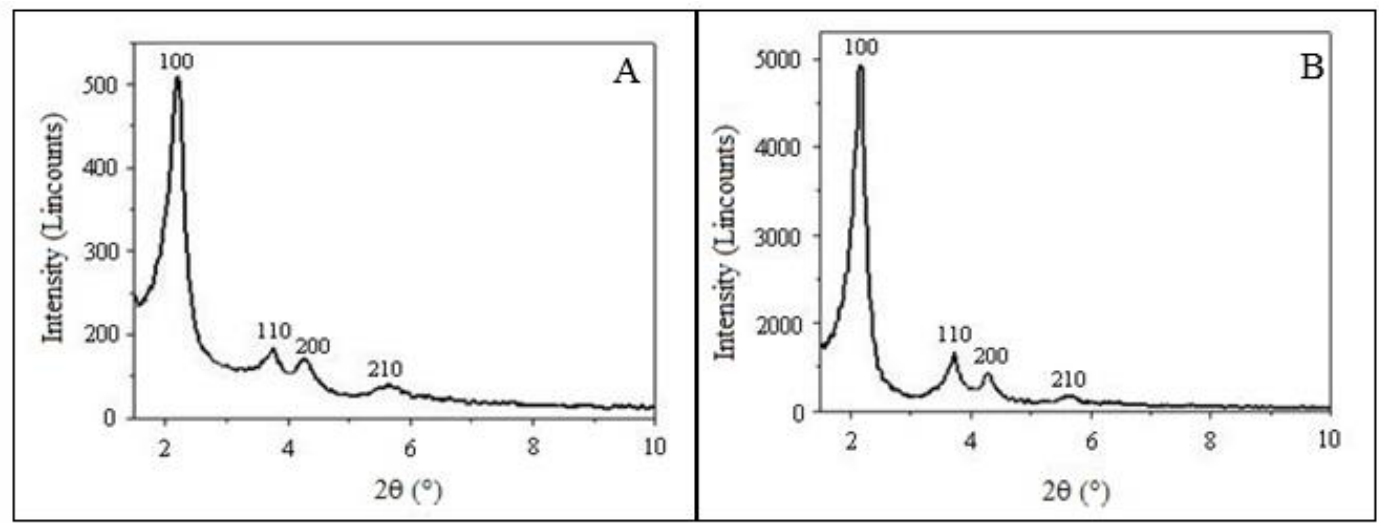

Figure 2. X-ray diffraction pattern obtained for the adsorbent Sr-MCM-41 before (A) and after calcination (B).

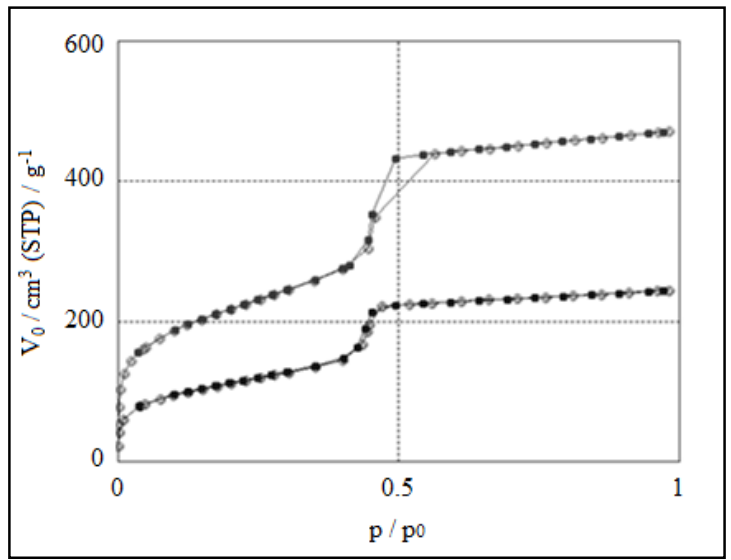

Figure 3. Isotherm for $\mathrm{N}_{2}$ adsorption/desorption from the adsorbent Sr-MCM-41 before $(A)$ and after calcination (B). Adsorption $(\bullet)$ and Desorption (०).

The crystallographic parameters derived via Xray diffraction for the adsorbent Sr-MCM- 41 before and after calcination can be verified in Table 2 .

After calcinations, the adsorbent Sr-MCM-41 increased the parameter a $a_{0}$ from $4.51 \mathrm{~nm}$ to $4.64 \mathrm{~nm}$, which means that the removal of the CTMABr template promoted the expansion of the network and improving the spatial network structure.

Table 2. Results of the X-ray diffraction for the adsorbent Sr-MCM-41.

\begin{tabular}{ccc}
\hline Properties & $\begin{array}{c}\text { Sr-MCM-41 } \\
\text { before } \\
\text { calcinations }\end{array}$ & $\begin{array}{c}\text { Sr-MCM-41 } \\
\text { after } \\
\text { calcinations }\end{array}$ \\
\hline $2 \theta$ & 2.26 & 2.20 \\
$d(n m) *$ & 3.91 & 4.02 \\
$a_{0}(n m)^{* *}$ & 4.51 & 4.64 \\
\hline${ }^{*}=$ average pore diameter of the material; ${ }^{* *} a_{0}=$ the \\
sum of the average pore diameter $(\mathrm{d})$ of the material.
\end{tabular}

\subsubsection{Textural characterization $\left(\mathbf{N}_{2}\right.$ adsorption/desorption using the BET and BJH methods)}

The isotherms for the adsorption/desorption of $\mathrm{N}_{2}$ from the Sr-MCM-41 adsorbent before and after calcination are shown in Figure 3.

Figure 3 shows that the isotherms are of type IV, as classified by the International Union of Pure and Applied Chemistry (IUPAC), and are characteristic of mesoporous materials (IUPAC, 1982). Analyzing the two isotherms, it appears that the material adsorbs a greater volume of $\mathrm{N}_{2}$ after calcination, suggesting that this material has a larger surface area, average pore diameter, and pore volume, as shown in Table 3.

According to the data presented in Table 3, the adsorbent showed pore diameter values between 20-500 A, which correspond to mesoporous 
Table 3. Textural characterization of the adsorbent using the BET and BJH methods.

\begin{tabular}{lcc}
\hline \multicolumn{1}{c}{ Characteristics } & $\begin{array}{c}\text { Sr-MCM-41 } \\
\text { before calcination }\end{array}$ & $\begin{array}{c}\text { Sr-MCM-41 } \\
\text { after calcinations }\end{array}$ \\
\hline BET surface area $\left[\mathrm{m}^{2} \cdot \mathrm{g}^{-1}\right]$ & 462.3 & 760.9 \\
Total pore volume at $\mathrm{P} / \mathrm{P}_{0} 0.98\left[\mathrm{~cm}^{3} \mathrm{~g}^{-1}\right]$ & 0.38 & 0.73 \\
Average pore volume $\left[\mathrm{cm}^{3}\left(\mathrm{STP}^{*}\right) \mathrm{g}^{-1}\right]$ & 106.2 & 174.8 \\
BJH pore volume $\left[\mathrm{cm}^{3} \mathrm{~g}^{-1}\right]$ & 0.35 & 0.64 \\
BET average pore diameter $(\AA)$ & 32.7 & 38.4 \\
BJH average pore diameter $(\AA)$ & 33.2 & 37.6 \\
\hline *STP - Standard Temperature and Pressure & &
\end{tabular}

materials, according to IUPAC (IUPAC, 1982), thereby confirming the observations in Figure 3. The increases in the surface area, diameter, volume, and area of the pores following calcination indicate that the calcination process was effective. These results are in agreement with the literature for MCM-41 (Beck et al., 1992; Chien et al., 2005; Silva, 2007a; Cai et al., 2011; Fu et al., 2011; Li et al., 2011; Saladino et al., 2011; Bing et al., 2012; Du \& Yang, 2012; Jiang et al., 2012a-b; Ghorbani et al., 2013).

\subsubsection{Chemical analysis}

An ICP-OES analysis of the solution obtained after acid digestion of the adsorbent found that the strontium content was $1.71 \%$, corresponding to $77 \%$ of the theoretical value calculated for the preparation of the adsorbent Sr-MCM-41. This result indicates the presence of the alkaline earth metal strontium into the adsorbent material.

\subsubsection{Fourier transform infrared spectroscopy (FT-IR)}

The Fourier-transformed infrared spectra of the adsorbent, before and after calcination, are shown in Figure 4.

The infrared absorption spectra of Sr-MCM-41 samples, before and after calcination, have bands in the $400-4000 \mathrm{~cm}^{-1}$ region, with peaks corresponding to fundamental vibration characteristics of the network of MCM-41. These results are in agreement with the literature (Silva, 2009a).

In the $1000-1250 \mathrm{~cm}^{-1}$ region, there is a band related to the asymmetrical stretching of the $\mathrm{Si}-\mathrm{O}-\mathrm{Si}$ bonds. This band is composed of two bands, one at $1030 \mathrm{~cm}^{-1}$ and the other at $1233 \mathrm{~cm}^{-1}$, and becomes less resolved when the material is calcined. The band at about $800 \mathrm{~cm}^{-1}$ refers to the symmetrical

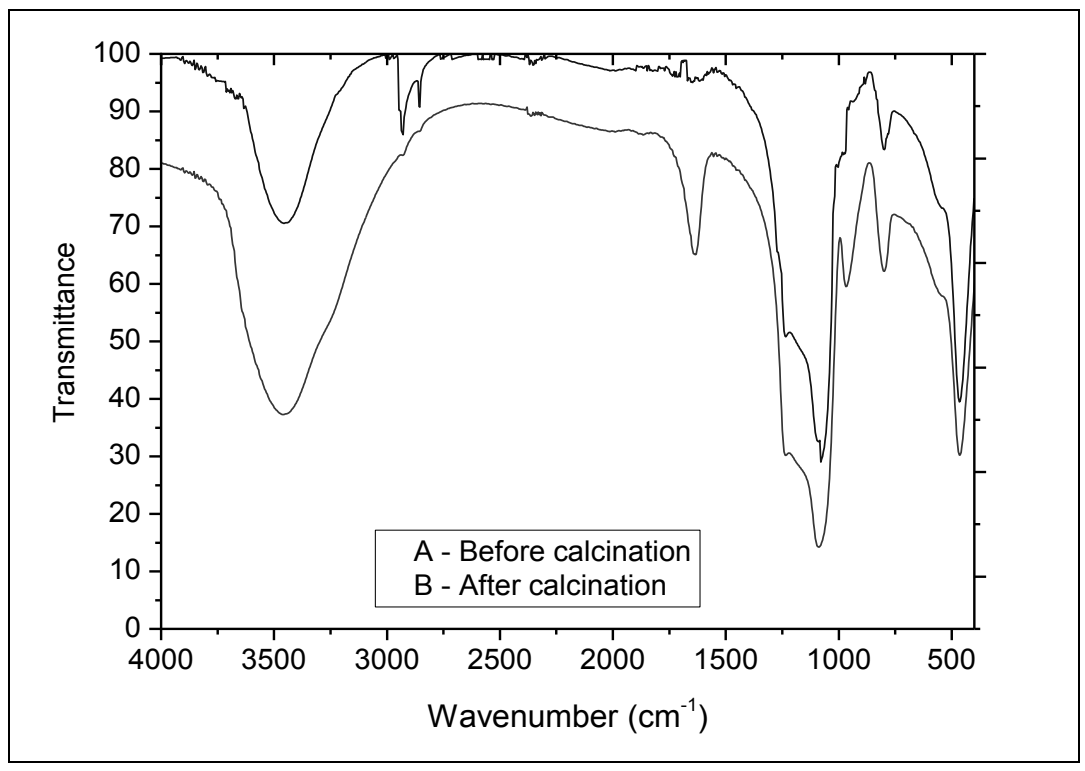

Figure 4. FT-IR spectra of the adsorbent Sr-MCM-41 before (A) and after calcination (B). 


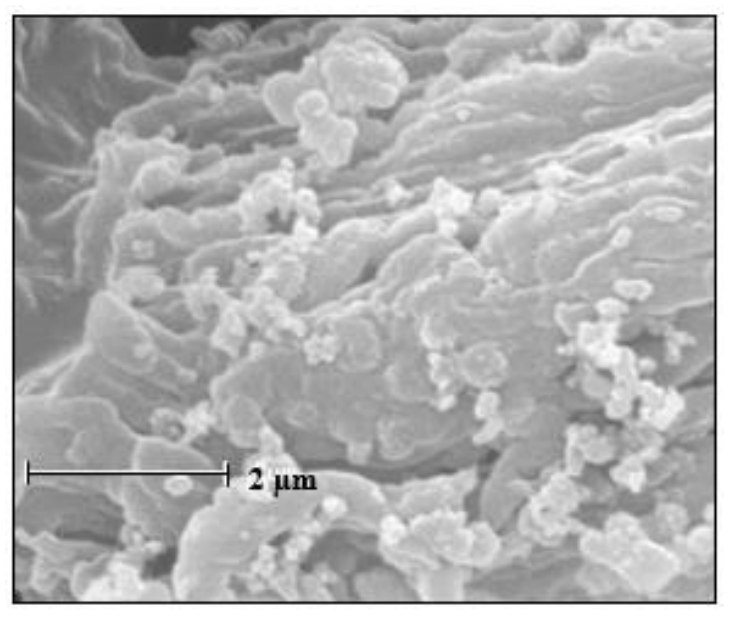

Figure 5. 8000x micrograph of the Sr-MCM41calcined adsorbent.

stretching of the Si-O-Si network. The deformation mode of vibration of the O-Si-O bonds is observed at $450 \mathrm{~cm}^{-1}$. The spectrum also shows a band of low intensity at $987 \mathrm{~cm}^{-1}$ that is ascribed to the stretching of $\mathrm{Si}-\mathrm{OH}$ and Si-OM ( $\mathrm{M}=$ metal) bonds.

The presence of the template can be confirmed by the bands in the $2820-2950 \mathrm{~cm}^{-1}$ region and is related to $\mathrm{C}-\mathrm{H}$ stretching. These bands, which are related to the directing agent, disappeared after calcination, indicating that the calcination process was effective in removing this compound. These results corroborate those found through the thermogravimetric analysis, whereby there was mass loss due to the removal of the structure directing agent.

The FT-IR spectrum also shows a broad absorption band at $3400 \mathrm{~cm}^{-1}$ corresponding to the stretching of the $\mathrm{OH}$ bond of water. These results are in agreement with those reported by Silva(2007a), Cai et al. (2011), Akondi et al. (2012), Du \& Yang (2012), Subhan et al. (2012), and Ghorbani et al. (2013).

\subsubsection{Scanning electron microscopy with energy dispersive spectroscopy (SEM/EDS)}

The scanning electron micrograph of mesoporous molecular sieve Sr-MCM-41 calcined at $500^{\circ} \mathrm{C}$ is shown in Figure 5.

Figure 5 shows the formation of tubular grains at the surface of the calcined adsorbent. This result is in agreement with the literature (Chien et al., 2005; Jiang et al., 2012a-b).

The energy dispersive X-ray spectrum of adsorbent Sr-MCM-41 is indicated in Figure 6.

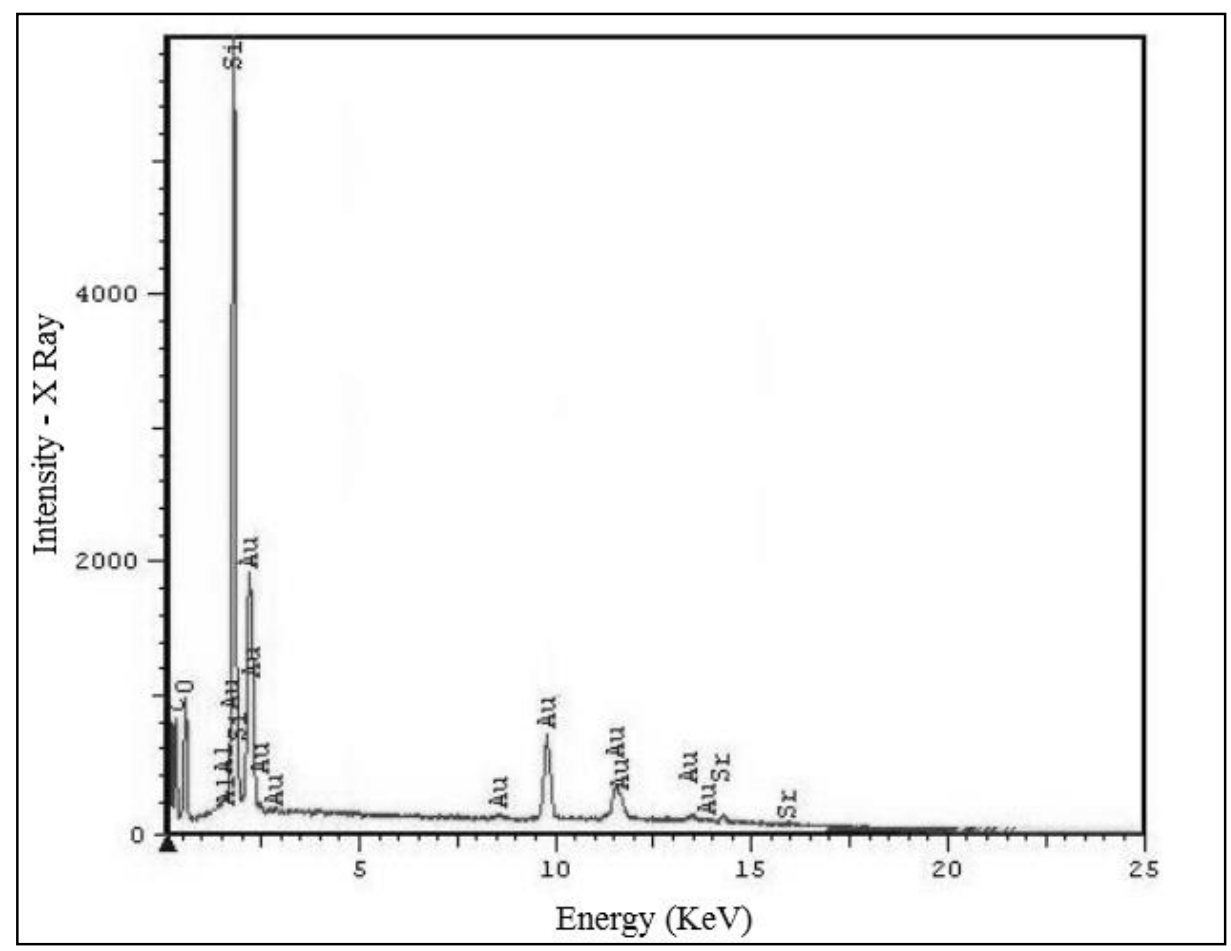

Figure 6. EDS spectra of the adsorbent Sr-MCM-41. 
Table 4. Matrix of $2^{3}$ factorial design.

\begin{tabular}{ccccc}
\hline Assays & $\begin{array}{c}\text { Mass } \\
\mathbf{( g )}\end{array}$ & $\begin{array}{c}\text { Concentration } \\
(\mathbf{w t .} \%)\end{array}$ & Stirring speed (rpm) & $\begin{array}{c}\mathbf{q} \\
\left(\mathbf{g ~ g}^{-1} \mathbf{)}\right.\end{array}$ \\
\hline 1 & $-1(0.05)$ & $-1(3)$ & $-1(220)$ & 0.30 \\
2 & $+1(0.15)$ & $-1(3)$ & $-1(220)$ & 0.22 \\
3 & $-1(0.05)$ & $+1(7)$ & $-1(220)$ & 0.07 \\
4 & $+1(0.15)$ & $+1(7)$ & $-1(220)$ & 0.05 \\
5 & $-1(0.05)$ & $-1(3)$ & $+1(420)$ & 0.60 \\
6 & $+1(0.15)$ & $-1(3)$ & $+1(420)$ & 0.27 \\
7 & $-1(0.05)$ & $+1(7)$ & $+1(420)$ & 0.94 \\
8 & $+1(0.15)$ & $+1(7)$ & $+1(420)$ & 0.38 \\
9 & $0(0.10)$ & $0(5)$ & $0(320)$ & 0.46 \\
10 & $0(0.10)$ & $0(5)$ & $0(320)$ & 0.42 \\
11 & $0(0.10)$ & $0(5)$ & $0(320)$ & 0.59 \\
\hline
\end{tabular}

Table 5. Main effects and interactions calculated for the $2^{3}$ factorial design, with their respective standard errors, expressed as \%. The effects that were considered statistically significant at $95 \%$ confidence level are shown in bold.

\begin{tabular}{lc}
\hline Effects & Results \\
\hline Average & $0.37 \pm 0.03$ \\
Main effects: & \\
M - Mass & $-\mathbf{0 . 2 8} \pm 0.06$ \\
C - Concentration & $-0.02 \pm 0.06$ \\
SS - Stirring speed & $\mathbf{0 . 3 5} \pm \mathbf{0 . 0 6}$ \\
Two-factor interaction: & \\
$M^{*} C$ & $-0.006 \pm 0.06$ \\
$M^{*} S S$ & $-0.16 \pm 0.06$ \\
$C^{*} S S$ & $0.25 \pm 0.06$ \\
Three-factor interaction: & \\
$M^{*} C * S S$ & $-0.11 \pm 0.06$ \\
\hline
\end{tabular}

The presence of strontium in the adsorbent $\mathrm{Sr}$ MCM-41 was observed because the EDS spectrum showed peaks that are characteristic of this metal. Peaks, due to silicon, presented the greatest intensity, followed by those of oxygen, which are constituents of the mesoporous material. Peaks related to the presence of gold and carbon were observed due to the metallization process by which the sample passed.

\subsection{Assessment of working conditions}

The results obtained in the study of working conditions using $2^{3}$ factorial design shown that the adsorbent Sr-MCM-41 is capable to remove naphthenic acids present in jet fuel, as it can be verified in Table 4.

Table 4 shows that the largest amount of naphthenic acid adsorbed per mass of adsorbent was $0.94 \mathrm{~g} \mathrm{~g}^{-1}$ (Test 7) and it was obtained when the mass of the adsorbent used was $0.05 \mathrm{~g}$, the solution of naphthenic acid had a concentration of $7 w t . \%$, and the stirring speed was 420rpm. Because the interaction effects were not significant, it was not possible to construct the response surfaces at the confidence levels studied.

The effects of the factors, the interactions among them and their respective standard errors, expressed as \%, were calculated according to Barros Neto et al. (2007) and are shown in Table 5.

Only the mass and stirring speed main effects were statistically significant at the confidence levels studied. These results can be better visualized through the Pareto chart obtained with the aid of the Statistica 6.0 software (Figure 7). 


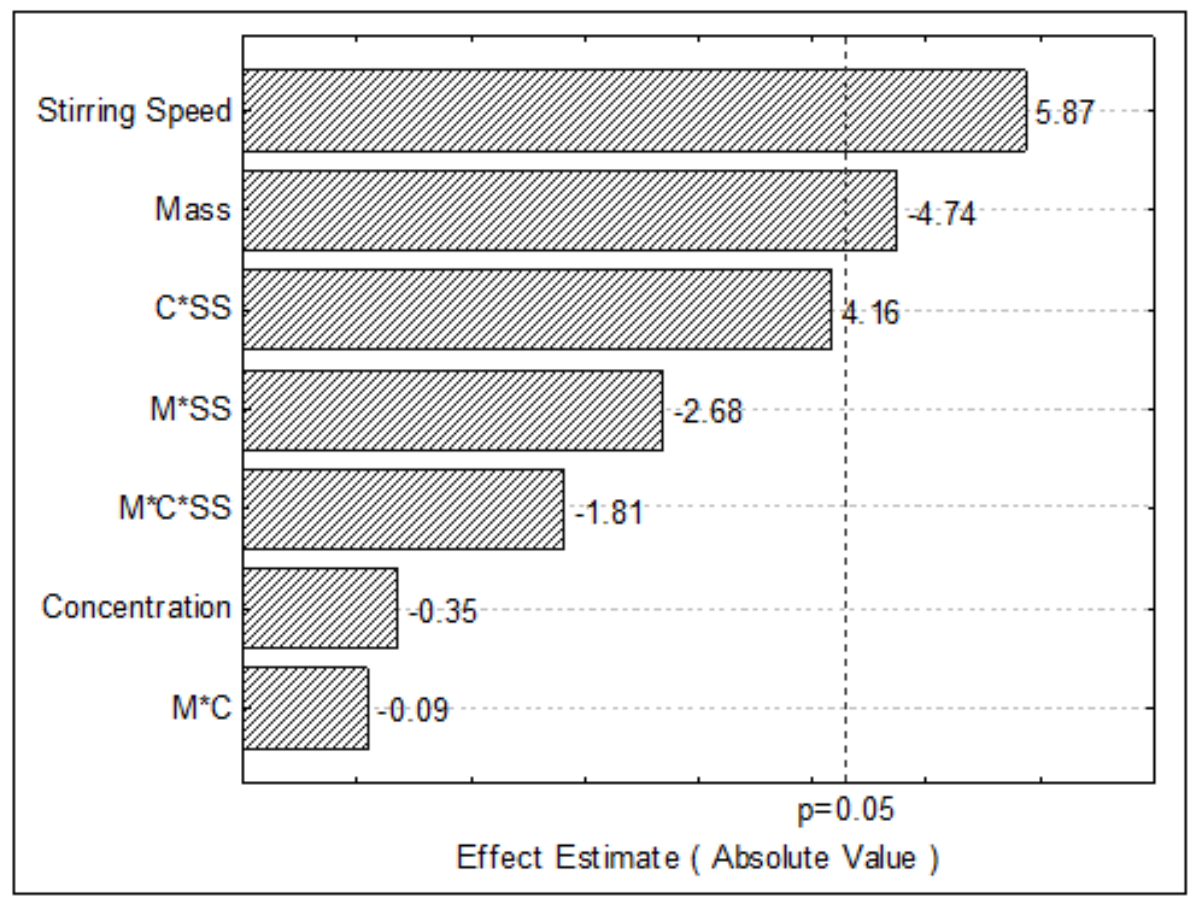

Figure 7. Pareto chart of effects calculated for the $2^{3}$ factorial design. Pure error $=0.008$.

Table 6. Comparison of adsorption capacity obtained in the factorial design study for the adsorbent with the highest capacity adsorbent available in the literature.

\begin{tabular}{lcc}
\hline Adsorbent & $\mathbf{q}$ (gacid $\mathbf{g}^{-1}$ adsorbent) & Reference \\
\hline Sr-MCM-41 & 0.94 & THIS WORK \\
Commercial clay & 0.019 to 0.025 & Silva et al. (2013) \\
Modified perovskite & 0.68 & Silva (2009b) \\
Activated carbon & 0.10 to 0.16 & Mohmed et al. (2008) \\
Polymeric materials & 0.02 to 0.03 & Mohmed et al. (2008) \\
MCM-41 & 0.62 & Silva (2007a) \\
Mg-MCM-41 & 1.48 & Silva (2007a) \\
Clay & 0.006 & Silva (2007b) \\
Activated alumina & 0.007 & Silva (2007b) \\
lon exchange resins & 0.069 & Silva (2007b) \\
\hline
\end{tabular}

As observed from Figure 7, the main effect of stirring speed was the most significant. Increasing the speed from $220 \mathrm{rpm}$ to $420 \mathrm{rpm}$ resulted in an average increase in the adsorption capacity of $70.9 \%$, where an increase in adsorbent mass from $0.05 \mathrm{~g}$ to $0.15 \mathrm{~g}$ resulted in an average decrease in the adsorption capacity of $51.8 \%$.

For comparative purposes, Table 6 presents the result for removal of naphthenic acids obtained in this study and other results found in literature. It is important to note that the adsorption capacity of this work is not the maximum adsorption capacity.

\section{CONCLUSIONS}

The method of synthesis used to obtain adsorbent Sr-MCM-41 was efficient because, according to the results of the BET analysis, it shows a type IV equilibrium adsorption isotherm, which is favorable for naphthenic acid removal.

The adsorbent Sr-MCM-41 showed good morphological and structural organization according to XRD and BET analyses. The calcination process employed in the synthesis of adsorbent led to the complete removal of CTMABr template, as indicated by the FT-IR and TG analyses. 
The technique of factorial design allowed us to observe the influences of variables on the adsorptive process. The largest amount of naphthenic acid adsorbed per mass of adsorbent was $0.94 \mathrm{~g} \mathrm{~g}^{-1}$, which was obtained when adsorbent amount was $0.05 \mathrm{~g}$, the acid concentration was $7 \mathrm{wt} . \%$, and the stirring speed was $420 \mathrm{rpm}$.

From the experimental results, one can conclude that the Sr-MCM-41 molecular sieve adsorbent presents technical potential for removing naphthenic acid from a model mixture of aviation fuel.

\section{ACKNOWLEDGEMENTS}

The authors would like to thank CNPQ, FINEP, and PETROBRAS for providing the financial resources needed for this work. The authors are also thankful to LACOM-UFPB, Analytical Center/DQFUFPE, and LQA/ITEP for analyzing the results of characterization.

\section{REFERENCES}

Akondi, A. M.; Trivedia, R.; Sreedhara, B.; Kantam, M. L.; Bhargava, S. Cerium-containing MCM-41 catalyst for selective oxidative arene crossdehydrogenative coupling reactions. Catalysis Today, v. 198, 35-44, 2012.

http://dx.doi.org/10.1016/i.cattod.2012.05.029

Anunziata, O. A.; Beltramone, A. R.; Cussa, J. Synthesis at atmospheric pressure and characterization of highly ordered Al, V, and TiMCM-41 mesostructured catalysts. Catalysis Today, v. 133-135, p. 891-896, 2008.

http://dx.doi.org/10.1016/j.cattod.2007.12.086

Araujo, A. S.; Jaroniec, M. Thermogravimetric monitoring of the MCM-41 synthesis.Thermochimica Acta, v. 175, p. 363, 2000.

Barros Neto, B.; Scarminio, I. S.; Bruns, R. E. Como Fazer Experimentos: Pesquisa e desenvolvimento na ciência e na indústria. Ed.Unicamp. Campinas-SP, 2007. 480p. (in Portuguese).
Beck, J.S; Vartuli J. C.; Roth W. J.; Leonowicz M. E.; Kresge C. T.; Schmitt K. D. A new family of mesoporous molecular sieves prepared with liquid cristal templates. Journal of American Chemical Society, v.114, p.10834-10843, 1992. http://dx.doi.org/10.1021/ja00053a020

Bing, J.; Li, L.; Lan, B.; Liao, G.; Zeng, J.; Zhang, Q.; $\mathrm{Li}, \mathrm{X}$. Synthesis of cerium-doped MCM-41 for ozonation of p-chlorobenzoic acid in aqueous solution. Applied Catalysis B: Environmental, v. 115-116, p. 16-24, 2012.

http://dx.doi.org/10.1016/j.apcatb.2011.12.017

Cai, C.; Wang, H.; Han, J. Synthesis and characterization of ionic liquid-functionalized alumino-silicate MCM-41 hybrid mesoporous materials. Applied Surface Science, v. 257, p. 98029808, 2011.

http://dx.doi.org/10.1016/j.apsusc.2011.06.025

Cai, Q.; Lin, W. Y.; Xiao, F. S.; Pang, W. Q.; Chen, X. H.; Zou, B. S. The preparation of highly ordered MCM-41 with extremely low surfactant concentration. Microporous Mesoporous Materials, v.32, p.1-15, 1999. http://dx.doi.org/10.1016/S1387-1811(99)00082-7

Chien, S.; Kuo, M.; Chen, C. Synthesis, Characterization and Catalysis of Ce-MCM-41. Journal of the Chinese Chemical Society, v. 52, p. 733-740, 2005.

Ding, L.; Rahimi, P.; Hawkins, R.; Bhatt, S.; Shi, Y. Naphthenic acid removal from heavy oils on alkaline earth-metal oxides and $\mathrm{ZnO}$ catalysts. Applied Catalysis A: General, v. 371, p. 121-130, 2009. http://dx.doi.org/10.1016/j.apcata.2009.09.040

Du, C.; Yang, $H$. Investigation of the physicochemical aspects from natural kaolin to AlMCM-41 mesoporous materials. Journal of Colloid and Interface Science, v. 369, p. 216-222, 2012. http://dx.doi.org/10.1016/i.jcis.2011.12.041

$\mathrm{Fu}$, J.; He, Q.; Wang, R.; Liu, B.; Hu, B. Comparative study of phenol compounds adsorption on mesoporous sieves with different degrees of modification. Colloids and Surfaces A: Physicochemical and Engineering Aspects, v. 375, p. 136-140, 2011.

http://dx.doi.org/10.1016/i.colsurfa.2010.11.078 
Gaikar, V. G.; Maiti, D. Adsorptive recovery of naphthenic acids using ion-exchange resins. Reactive \& Functional Polymers, v.31, p.155-164, 1996. http://dx.doi.org/10.1016/1381-5148(96)00054-5

Ghorbani, F; Younesi, H.; Mehraban, Z.; Çelik, M. S.; Ghoreyshi, A. A.; Anbia, M. Preparation and characterization of highly pure silica from sedge as agricultural waste and its utilization in the synthesis of mesoporous silica MCM-41. Journal of the Taiwan Institute of Chemical Engineers. 2013. In Press, Corrected Proof.

http://dx.doi.org/10.1016/j.jtice.2013.01.019

Hau, J. Predicting Sulfidic and Naphthenic Acid Corrosion. Corrosion, v. 65, p. 831-844. 2009. http://dx.doi.org/10.5006/1.3319109

Huang, M. F.; Zhao, S. L.; Li, P.; Huisingh, D. Removal of naphthenic acid by microwave. Journal of Cleaner Production, v. 14, p. 736-739. 2006. http://dx.doi.org/10.1016/j.jclepro.2005.04.004

International Union of Pure and Applied Chemistry (IUPAC). Reporting Physisorption data for gas/solid systems.v. 54, p. 2201-2218, 1982.

Jiang, T. S.; Zhao, Q.; Yin, H. B. Synthesis of highly stabilized mesoporous molecular sieves using natural clay as raw material. Applied Clay Science, v. 35, p. 155-161, 2007.

http://dx.doi.org/10.1016/i.clay.2006.08.007

Jiang, C.; Su, A.; Li, X.; Zhou, T.; He, D. Study on the hydrothermal stability of MCM-41 via secondary restructure. Powder Technology, v. 221, p. 371-374, 2012a. http://dx.doi.org/10.1016/i.powtec.2012.01.028

Jiang, T.; Qi, L.; Ji, M.; Ding, H.; Li, Y.; Tao, Z.; Zhao, Q. Characterization of $\mathrm{Y} / \mathrm{MCM}-41$ composite molecular sieve with high stability from Kaolin and its catalytic property. Applied Clay Science, v. 62-63, p. 32-40, 2012b.

http://dx.doi.org/10.1016/i.clay.2012.04.016

Li, X.; Li, B.; Xu, J.; Wang, Q.; Pang, X.; Gao, X.; Zhou, Z.; Piao, J. Synthesis and characterization of Ln-ZSM-5/MCM-41 ( $\mathrm{Ln}=\mathrm{La}, \mathrm{Ce}$ ) by using kaolin as raw material. Applied Clay Science, v. 50, p. 81-86, 2010. http://dx.doi.org/10.1016/j.clay.2010.07.006
Li, Y.; Yan, B.; Wang, L. Rare earth (Eu3+, Tb3+) mesoporous hybrids with calix[4]arene derivative covalently linking MCM-41: Physical characterization and photoluminescence property. Journal of Solid State Chemistry, v. 184, p. 25712579, 2011.

http://dx.doi.org/10.1016/j.jssc.2011.07.040

Mohamed, M. H.; Wilson, L. D. ; Headley, J. V. ; Peru, K. M. Novel materials for environmental remediation of tailing pond waters containing naphthenic acids. Process Safety and Environment Protection, v. 86, p. 237-243, 2008.

http://dx.doi.org/10.1016/j.psep.2008.04.001

Nilsen, M. H.; Antonakou, E.; Bouzga, A.; Lappas, A.; Mathisen, K.; Stocker, M. Investigation of the effect of metal sites in Me-Al-MCM-41 ( $\mathrm{Me}=\mathrm{Fe}, \mathrm{Cu}$ or $\mathrm{Zn}$ ) on the catalytic behavior during the pyrolysis of wooden based biomass. Microporous and Mesoporous Materials, v. 105, p. 189-203, 2007. http://dx.doi.org/10.1016/i.micromeso.2007.05.059

Northcott, K. A.; Miyakawa, K.; Oshima, S.; Komatsu, Y.; Perera, J. M.; Stevens, G. W. The adsorption of divalent metal cations on mesoporous silicate MCM-41. Chemical Engineering Journal, v. 157, p. 25-28, 2010.

http://dx.doi.org/10.1016/i.cej.2009.10.038

Oliveira, A. C.; Range, M. C.; Fierro, J. L. G.; Reyes, P.; Oportus, M. Efeito do Cromo nas Propriedades Catalíticas da MCM-41. Química Nova, v. 28, p. 3741, 2005. (in Portuguese) http://dx.doi.org/10.1590/S0100-40422005000100007

Park, S. H.; Kim, B. H.; Selvaraj, M.; Lee, T. G. Synthesis and Characterization of Mesoporous CeMn-MCM-41 Molecular Sieves. Journal of Industrial and Engineering Chemistry, v. 13, p. 637-643, 2007.

Petkova, N; Angelova, M.; Petkov, P. Establishing the reasons and type of the enhanced corrosion in the crude oil atmospheric distillation unit. Petroleum \& Coal, v. 51, p. 286-292, 2009.

Rezaei Gomari, K. A.; Denoyel, R.; Hamouda, A. A. Wettability of calcite and mica modified by different long-chain fatty acids. Journal of Colloid and Interface Science, v. 297, p. 470-479, 2006. http://dx.doi.org/10.1016/j.jcis.2005.11.036 
Saladino, M. L.; Kralevab, E.; Todorova, S.; Spinellac, A.; Nasilloc, G.; Caponetti, E. Synthesis and characterization of mesoporous Mn-MCM-41 materials. Journal of Alloys and Compounds, v. 509, p. 8798-8803, 2011.

http://dx.doi.org/10.1016/j.jallcom.2011.06.078

Silva, G. A. Remoção de ácidos naftênicos por adsorção utilizando peneiras moleculares do tipo MCM-41. 114F. Dissertação de Mestrado. Programa de Pós-Graduação em Engenharia Química da Universidade Federal de Pernambuco, 2007a. (in Portuguese).

Silva, J. P. Estudo de adsorção de ácidos naftênicos a partir de correntes de hidrocarbonetos. 116F. Dissertação de Mestrado. Programa de Pós-Graduação em Engenharia Química do Instituto de Química da Universidade do Estado do Rio de Janeiro - Instituto de Química, 2007b. (in Portuguese).

Silva, M. L. S. Síntese e Caracterização de Peneiras Moleculares Mesoporosas do tipo MCM41 e AIMCM-41 a partir de fontes alternativas de sílica e de alumínio. 82F. Tese de Doutorado. Programa de Pós-Graduação em Ciência e Engenharia de Materiais da Universidade Federal do Rio Grande do Norte, 2009a. (in Portuguese).

Silva, R. L. Remoção de Ácidos Naftênicos presentes na mistura modelo de Querosene de Aviação utilizando Adsorventes do Tipo Perovsquitas Modificadas. 120F. Dissertação de Mestrado. Programa de Pós-Graduação em Engenharia Química da Universidade Federal de Pernambuco, 2009b. (in Portuguese).

Silva, J. C. M. Preparação e caracterização de catalisadores mesoporosos modificados do tipo MCM-41. 72F. Dissertação de Mestrado. Programa de Pós-Graduação em Química do Instituto de Química da Universidade de Brasília, 2009c. (in Portuguese).
Silva, J. P.; Costa, A. L. H.; Chiaro, S. S. X.; Delgado, B. E. P. C.; Figueiredo, M. A. G.; Lilian F. Senna, L. F. Carboxylicacid removal from model petroleum fractions by a comercial clay adsorbent. Fuel Processing Technology, v. 112, p. 57-63, 2013. http://dx.doi.org/10.1016/j.fuproc.2012.07.033

Subhan, F.; Liu, B. S.; Zhang, Y.; Li, X. G. High desulfurization characteristic of lanthanum loaded mesoporous MCM-41 sorbents for diesel fuel. Fuel Processing Technology, v. 97, p. 71-78, 2012. http://dx.doi.org/10.1016/j.fuproc.2012.01.016

Wu, G.; Jiang, S.; Li, L.; Guan, N. Nitridation of $\mathrm{BaO}$ supported on mesoporous materials: Basicity characterization and catalytic properties. Applied Catalysis A: General, v. 391, p. 225-233, 2011. http://dx.doi.org/10.1016/i.apcata.2010.07.033

Zhan W., Lu, G.; Guo, Y.; Guo, Y.; Wang, Y. Synthesis of Ln-doped MCM-41 mesoporous materials and their catalytic performance in oxidation of styrene. Journal of Rare Earths, v. 26, p. 59-65, 2008.

http://dx.doi.org/10.1016/S1002-0721(08)60038-1

Zhang, J.; Shena, Z.; Shanc, W.; Meia, Z.; Wanga, W. Adsorption behavior of phosphate on lanthanum(III)-coordinated diamino-functionalized 3D hybrid mesoporous silicates material. Journal of Hazardous Materials, v. 186, p. 76-83, 2011. http://dx.doi.org/10.1016/j.jhazmat.2010.10.076

Zhao, Q.; Wang, G. W.; Wu, D. L.; Zhou, X. P.; Jiang, T. S. Microwave synthesis and textural property of europium substituted mesoporous molecular sieves. Journal of Physics and Chemistry of Solids, v. 72, p. 34-38. 2011. http://dx.doi.org/10.1016/j.jpcs.2010.10.083

Zou, L.; Han, B.; Yan, H.; Kaperski, K. L.; Xu, Y.; Hepler, L. G. Enthalpy of adsorption and isotherms for adsorption of naphtenic acid onto clays. Journal of Colloid and Interface Science, v.190, p. 472-475, 1997. http://dx.doi.org/10.1006/icis.1997.4898 